7. Reprod. Fert. (1970) 22, 345-356

\title{
REDUCTION OF FERTILITY IN FEMALE MICE ISO-IMMUNIZED WITH A SUB-CELLULAR SPERM FRACTION
}

\author{
E. B. BELL* AND ANNE McLAREN $\dagger$ \\ Institute of Animal Genetics, University of Edinburgh \\ (Received 11th August 1969, revised 23rd December 1969)
}

\begin{abstract}
Summary. Mouse spermatozoa were disrupted in a pressure cell and separated by centrifugation at $1200 \mathrm{~g}$ into supernatant and sediment components. Sperm head nuclei were isolated from the sediment by a sucrose gradient ultracentrifugation procedure. Injection of the alumprecipitated supernatant fraction into female mice significantly reduced both litter size $(P<0.001)$ and fertilization rate $(P<0 \cdot 001)$. Fertility was depressed to a lesser degree by the same antigen when it had not been precipitated. The injection of isolated sperm-head nuclei had no significant effect on litter size or fertilization rate.

Serum antibody against spermatozoa was measured by passive haemagglutination as well as sperm agglutination. Passive haemagglutination titres were significantly higher in mice injected with supernatant preparations than in those receiving whole spermatozoa or sediment fractions. Freezing the supernatant before injection abolished the sperm agglutination titre but did not reduce the degree of impairment of fertility, indicating that sperm agglutinins were not responsible for the induced infertility.
\end{abstract}

\section{INTRODUCTION}

Immunization of females with homologous spermatozoa or testis homogenates has resulted in a reduction of fertility in mice (McLaren, 1964, 1966; Edwards, 1964; Bell, 1969a), rabbits (Menge, 1968; Bell, 1969b), cattle (Menge, 1967, 1969) and guinea-pigs (Isojima, Graham \& Graham, 1959; Katsh, 1959). However, the complex nature of the injected material precludes an accurate analysis of the factors operating to bring about this state of infertility. Examination of serum titres has failed to yield any consistent relationship between infertility and antibody concentration. Little is known of the nature of the 'active' sperm antigens, the properties of the antibody involved or the location in the reproductive tract where antibodies (or antibody-producing cells) exert their effect.

In the work described here, female mice were immunized with supernatant

* Present address: Department of Experimental Immunobiology, The Wellcome Research Laboratories, Langley Court, Beckenham, Kent.

$\dagger$ Agricultural Research Council Unit of Animal Genetics. 
and sediment fractions of mouse spermatozoa. The sediment fraction was purified in a morphological sense, in that it contained a homogeneous suspension of nuclear material from the sperm head. Antigenicity of the supernatant and sediment fractions was investigated after alum precipitation or freezing. The effect of the various sperm antigen preparations on fertility was evaluated in terms of litter size and percentage of fertilized eggs. Antibodies measured by the sperm agglutination and passive haemagglutination tests were analysed for their possible involvement in the depression of fertility.

Mice

\section{MATERIALS AND METHODS}

Epididymal spermatozoa were collected from male mice of the random-bred $Q$ strain, 3 to 8 months old. $Q$ strain females, 3 to 4 months old, were used for breeding experiments.

\section{Fractionation of spermatozoa}

Spermatozoa were teased from the excised vas deferens and epididymis, suspended in $\mathrm{pH} 7.2$ phosphate-buffered saline, pooled, washed once and suspended at $6 \times 10^{7}$ spermatozoa $/ \mathrm{ml}$ in phosphate-buffered saline. The spermatozoa were disrupted in a Ribi Cell Fractionator at a pressure of 20,000 and again at 30,000 pounds per square inch. Particulate material was removed by centrifugation at $1200 \mathrm{~g}$. The supernatant was stored at $4^{\circ} \mathrm{C},-20^{\circ} \mathrm{C}$ or alum-precipitated with an equal volume of $1 \%$ aluminium potassium sulphate. Before injection, this latter preparation was centrifuged and resuspended to the original volume.

\section{Isolation of sperm head nuclei}

Microscopic examination of the sediment of the disrupted spermatozoa revealed a predominance of sperm-head nuclei. These nuclei could be isolated in a relatively pure form by high speed centrifugation in a sucrose gradient. The sediment, resuspended in $10 \%$ sucrose $(\mathrm{w} / \mathrm{v})$, was overlayered on $70 \%$ sucrose $(\mathrm{w} / \mathrm{v})$ and the interface gently stirred with a glass rod to form a gradient. The preparation was centrifuged at $25,000 \mathrm{rev} / \mathrm{min}$ in a Beckman Model L (swing out head 113.4) at $4^{\circ} \mathrm{G}$ for $1 \mathrm{hr}$. Several bands appeared in the gradient, but contained few or no sperm heads. The pellet appeared to be composed entirely of sperm-head nuclei. The isolated sperm heads were washed twice in phosphatebuffered saline before injection.

\section{Antigens}

The following preparations were injected into groups of female mice: the supernatant fraction of disrupted mouse spermatozoa (Group Sup); the same preparation alum-precipitated (Group Sup-A); nuclear material from the sperm head (Group Sed); the same material alum-precipitated (Group Sed-A); whole spermatozoa (Group Sp); sterile saline (Group $\mathrm{C}$ ). The injection of spleen cells, as a control for the frequent injection of homologous male protein, was previously shown to have no significant effect on fertility (McLaren, 1962). 
Injections

All mice were injected intraperitoneally with $0 \cdot 1-\mathrm{ml}$ aliquots of antigen (containing the equivalent of $6 \times 10^{7}$ spermatozoa $/ \mathrm{ml}$ ) or saline three times weekly for 8 weeks. Following a period of breeding, females were again injected three times a week for 4 weeks.

\section{Serum}

Blood samples were collected from the retro-orbital venous plexus 10 days after the last injection or on the day a copulation plug was found. Serum was drawn off the clot, diluted with an equal volume of phosphate-buffered saline and stored at $-20^{\circ} \mathrm{G}$.

\section{Immunological assays}

Humoral antibody responses were assayed using the sperm agglutination test (McLaren, 1964) and the passive haemagglutination test (Bell, 1969a).

\section{Breeding and fertilization}

Ten days after completion of the first injection series, mice were paired with known fertile males for 38 consecutive days (sufficient time for no more than two litters). Offspring were sexed, counted and removed on the day of birth. Following re-immunization, some mice were subjected to long-term breeding ( 4 months); the remainder were exsanguinated 2 days after identification of a copulation plug, and the eggs from Fallopian tubes were examined for evidence of fertilization. Eggs were regarded as fertilized if they had undergone one or more normal cleavages.

\section{RESULTS}

Effect on litter size

An analysis of variance of mean litter sizes for the first and first plus second litters indicated that there were significant differences $(P<0.001)$ between group treatments. Student's $t$ test was applied to appropriate pairs of means and the results are summarized in Table 1 . Injection of the alum-precipitated supernatant fraction (Group Sup-A) reduced $(P<0.001)$ the number of offspring both in the first litter and in the first two litters combined. The reduction was equivalent to that produced by injection of whole spermatozoa (Group Sp). Mice injected with the supernatant fraction which had not been alum-precipitated (Group Sup), showed a small decrease in litter size, not significant at the $5 \%$ level. The temperature at which the antigen was stored had no effect on litter size (first + second litter: $+4^{\circ} \mathrm{C}, 16 \cdot 83 \pm 1 \cdot 11 ;-20^{\circ} \mathrm{C}, 17 \cdot 66 \pm 2 \cdot 20$ ). Although injection of the nuclear head fraction alone had no significant effect (Group $\mathrm{G}$ versus Sed), females receiving the alum-precipitated sediment fraction showed a mean litter size significantly smaller than that of the controls, though significantly larger than that of the females receiving the alum-precipitated supernatant fraction $(P<0.01$ after two litters).

Samples of mice from Groups C, Sed-A and Sup-A were paired continuously for 4 months after re-immunization. As in the first period of immunization, a 
significant reduction in litter size was obtained in the mice injected with the supernatant (Table 2). However, the mice injected with the sediment proved as

TABLE 1

SUMMARY OF COMPARISONS (T TEST) OF MEAN LITTER SIZES BETWEEN GROUPS FOR THE FIRST AND THE FIRST PLUS SEGOND LITTERS

\begin{tabular}{|c|c|c|c|c|c|c|}
\hline & \multicolumn{6}{|c|}{ Group } \\
\hline & C & Sed & Sed-A & Sup & $S u p-A$ & $S p$ \\
\hline $\begin{array}{c}\text { FIRST LITTER } \\
\text { No. of mice } \\
\text { Mean } \pm \\
\text { S.E. } \\
\text { Group } \\
\text { Sp } \\
\text { Sup-A } \\
\text { Sup } \\
\text { Sed-A } \\
\text { Sed }\end{array}$ & $\begin{array}{c}33 \\
10.97 \pm 0.45 \\
<0.001 \\
<0.001 \\
>0.05 \\
<0.02 \\
\text { NS }\end{array}$ & $\begin{array}{c}22 \\
10.41 \pm 0.57 \\
<0.005 \\
\text { NS } \\
>0.05\end{array}$ & $\begin{array}{c}22 \\
8.77 \pm 0.74 \\
>0.05 \\
>0.1\end{array}$ & $\begin{array}{c}21 \\
9.43 \pm 0.76 \\
<0.05 \\
<0.05\end{array}$ & $\begin{array}{c}22 \\
7 \cdot 09 \pm 0 \cdot 81 \\
\text { NS }\end{array}$ & $\begin{array}{c}12 \\
6 \cdot 08 \pm 1 \cdot 12\end{array}$ \\
\hline $\begin{array}{l}\text { FIRST }+ \\
\text { SECOND } \\
\text { LITTER } \\
\text { No. of mice } \\
\text { Mean } \pm \\
\text { S.E. } \\
\text { Group } \\
\text { Sp } \\
\text { Sup-A } \\
\text { Sup } \\
\text { Sed-A } \\
\text { Sed }\end{array}$ & $\begin{array}{c}33 \\
20.09 \pm 0.95 \\
<0.001 \\
<0.001 \\
>0.05 \\
<0.02 \\
\text { NS }\end{array}$ & $\begin{array}{c}22 \\
19 \cdot 18 \pm 0.97 \\
<0.001 \\
\text { NS } \\
>0.1\end{array}$ & $\begin{array}{c}22 \\
16.95 \pm 1 \cdot 11 \\
<0.01 \\
<0.01\end{array}$ & $\begin{array}{c}21 \\
17 \cdot 19 \pm 1 \cdot 11 \\
<0.01 \\
<0.01\end{array}$ & $\begin{array}{c}22 \\
12 \cdot 71 \pm 1 \cdot 01 \\
\text { NS }\end{array}$ & $\begin{array}{c}12 \\
10 \cdot 83 \pm 1 \cdot 83\end{array}$ \\
\hline
\end{tabular}

TABLE 2

COMPARISON OF MEAN NUMBER OF OFFSPRING PER FEMALE IN SEDIMENT-, SUPERNATANT- AND SALINE-INJEGTED MICE AFTER RE-IMMUNIZATION AND AFTER A TOTAL OF 6 MONTHS' PAIRING WITH MALES

\begin{tabular}{l|c|c|c}
\hline & \multicolumn{3}{|c}{ Group } \\
\cline { 2 - 4 } & $C$ & Sed-A & Sup-A \\
\hline $\begin{array}{l}\text { THIRD LITTER } \\
\text { No. of mice } \\
\text { Mean } \pm \text { S.E. }\end{array}$ & 10 & 11 & 12 \\
\hline $\begin{array}{l}\text { THIRD + FouRTH LITTER } \\
\text { No. of mice } \\
\text { Mean } \pm \text { S.E. }\end{array}$ & $13 \cdot 10 \pm 1 \cdot 85 \pm 1 \cdot 40$ & $8 \cdot 27 \pm 0 \cdot 79$ & $5 \cdot 00 \pm 1 \cdot 24^{*}$ \\
\hline $\begin{array}{l}\text { MonTHS TotAL } \\
\text { No. of mice } \\
\text { Mean } \pm \text { S.E. }\end{array}$ & 10 & 11 & 12 \\
\hline
\end{tabular}

Comparison with Group: Sed-A $* P<0 \cdot 02$.

C $\dagger P<0.05$.

fertile as the controls, suggesting that the small mean litter size seen in this group during the earlier period was an accident of sampling. 
Effect on fertilization

Evidence in the mouse (McLaren, 1964; Edwards, 1964) suggested that the effect on litter size of injecting whole spermatozoa was attributable to a decreased fertilization rate. To ascertain if injection of the supernatant fraction was affecting a similar stage in the reproductive process, eggs were examined for evidence of fertilization in all groups following re-immunization. In testing differences between treatments, two parameters were investigated: numbers of sub-fertile mice (less than 100\% fertilization) and numbers of unfertilized eggs.

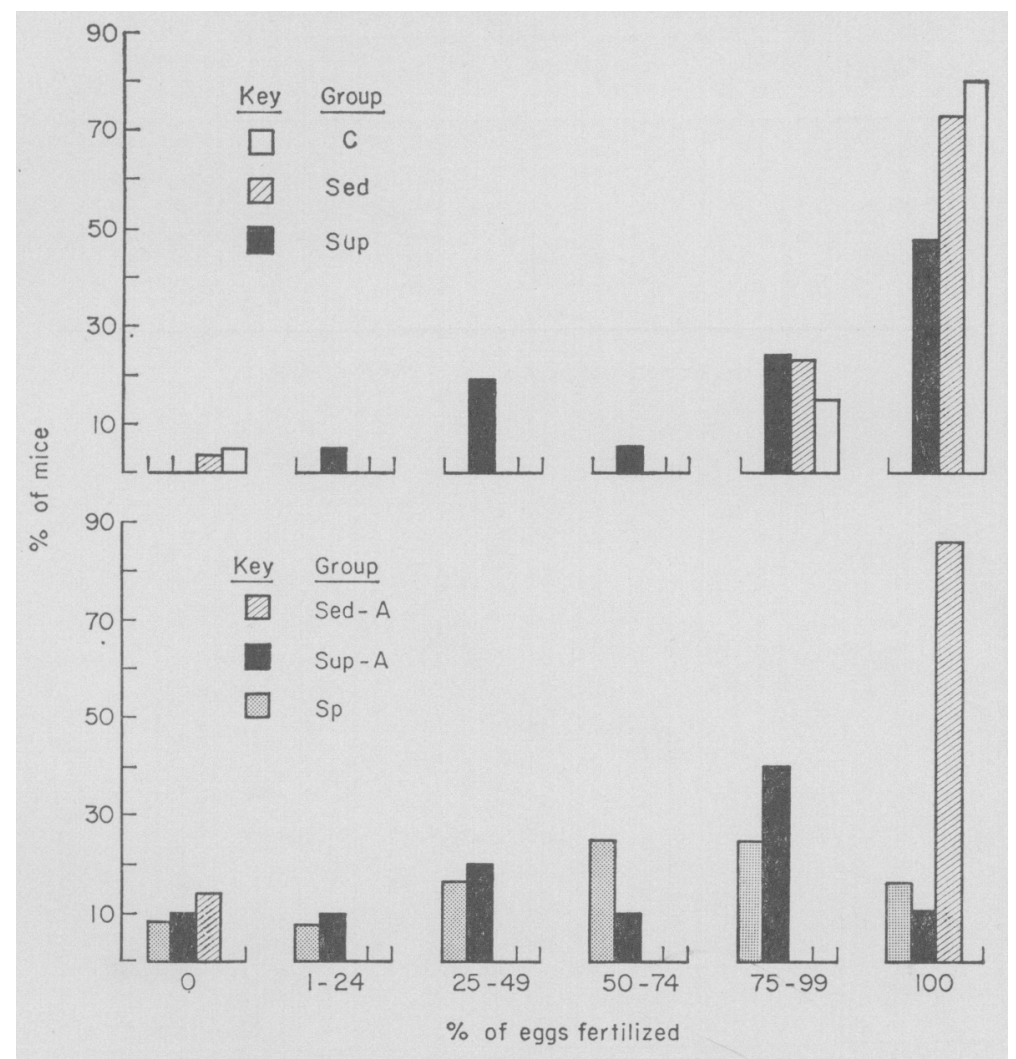

TExT-FIG. 1. Distribution of mice of Groups C, Sed, Sed-A, Sup, Sup-A and Sp according to percentage of eggs fertilized.

The distribution of females according to the number of eggs fertilized is shown for the different groups in Text-fig. 1. The number of mice showing less than $100 \%$ fertilization was significantly lower in the controls than in those injected either with the supernatant (Group Sup-A, $P<0.001$ ) or with whole spermatozoa (Group Sp, $P<0 \cdot 005$ ). In Group Sup, a smaller number of mice showed less than $100 \%$ fertilization, the difference not reaching the $5 \%$ level of significance $(P=0.072)$. Mice injected with sediment (Groups Sed and Sed-A) were no different from the controls.

In testing the effect of immunization on fertilization rate, mice in which no fertilized eggs were recovered (one each in Groups C, Sed, Sed-A, Sup-A and

$\mathbf{L}$ 
$\mathrm{Sp}$ ) were excluded from the analysis (Ghi square), since complete failure to fertilize could have been due to some defect unrelated to the treatment, such as an obstruction within the reproductive tract or an inadequate ejaculate from

TABLE 3

NUMBER OF FERTILIZED AND UNFERTILIZED EGGS RECOVERED FROM MICE AFTER RE-IMMUNZZATION

\begin{tabular}{l|c|cc|c}
\hline \multirow{2}{*}{ Group } & & \multicolumn{2}{|c|}{ Eggs } & \\
\cline { 3 - 4 } & $\begin{array}{c}\text { No. of } \\
\text { mice }\end{array}$ & Unfertilized & Fertilized & \% fertilization \\
\hline C & 19 & 10 & 236 & $95 \cdot 9$ \\
Sed & 21 & 8 & 264 & $97 \cdot 1$ \\
Sed-A & 6 & 0 & 83 & $100 \cdot 0$ \\
Sup & 21 & 61 & 213 & $77 \cdot 7 * * *$ \\
Sup-A & 9 & 37 & 81 & $68 \cdot 6^{* * *}$ \\
Sp & 11 & 51 & 84 & $62 \cdot 2^{* * *}$ \\
\hline
\end{tabular}

Comparison with controls: $* * * P<0.001$.

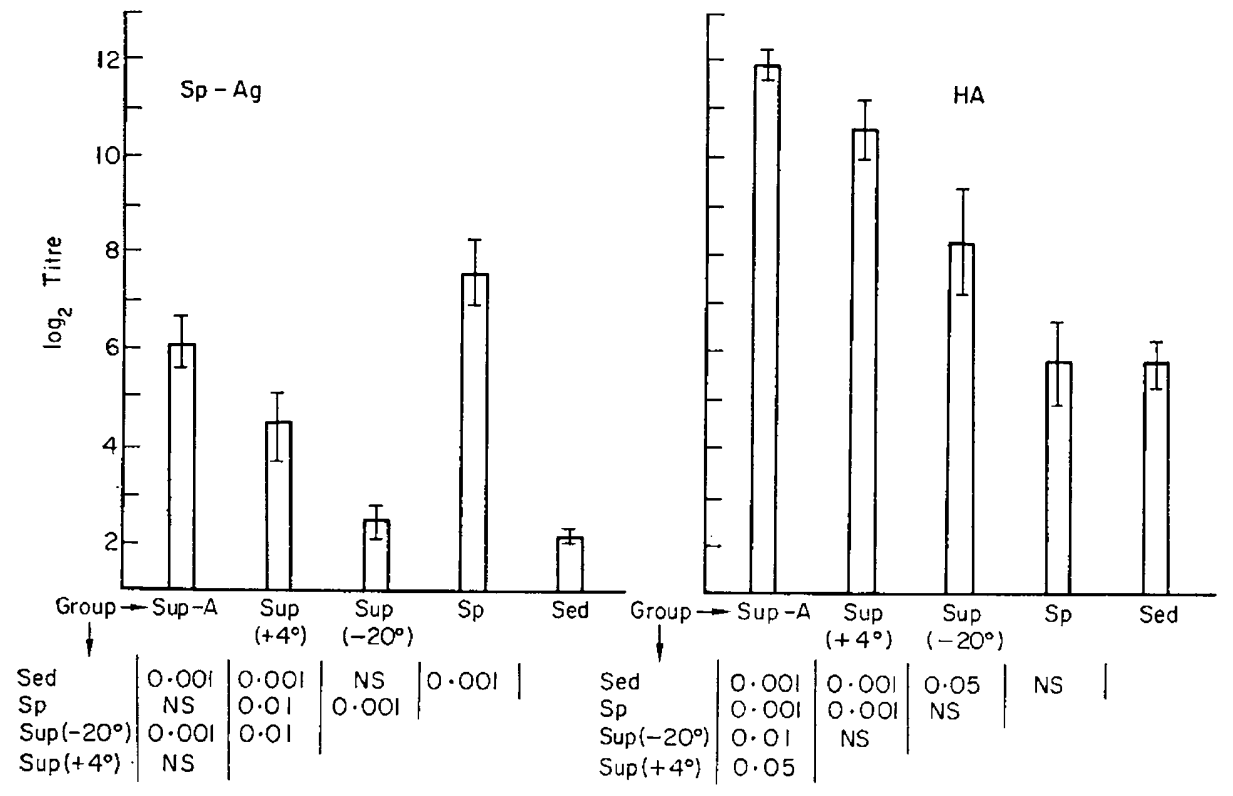

TexT-Fig. 2. Summary of mean titres \pm S.E. for the sperm agglutination (Sp-Ag) and haemagglutination (HA) tests after the first immunization period. The level at which the null hypothesis was rejected $(t$ test $)$ is given for the pairs indicated. $(P<$ value given; NS $=P>0.05$ )

the male. The fertilization rates shown in Table 3 are in agreement with the preceding analysis on numbers of mice showing less than $100 \%$ fertilization. However, in addition to the group injected with the alum-precipitated super- 
natant, the group immunized with the non-precipitated antigen showed a significantly lower fertilization rate $(P<0.001)$ than control or sedimentinjected mice. Fertilization rate in Group Sup was low irrespective of whether the antigen had been stored at $+4^{\circ} \mathrm{C}(77.0 \%)$ or $-20^{\circ} \mathrm{C}(78.8 \%)$. Neither Group Sed nor Sed-A appeared different from mice injected with saline.

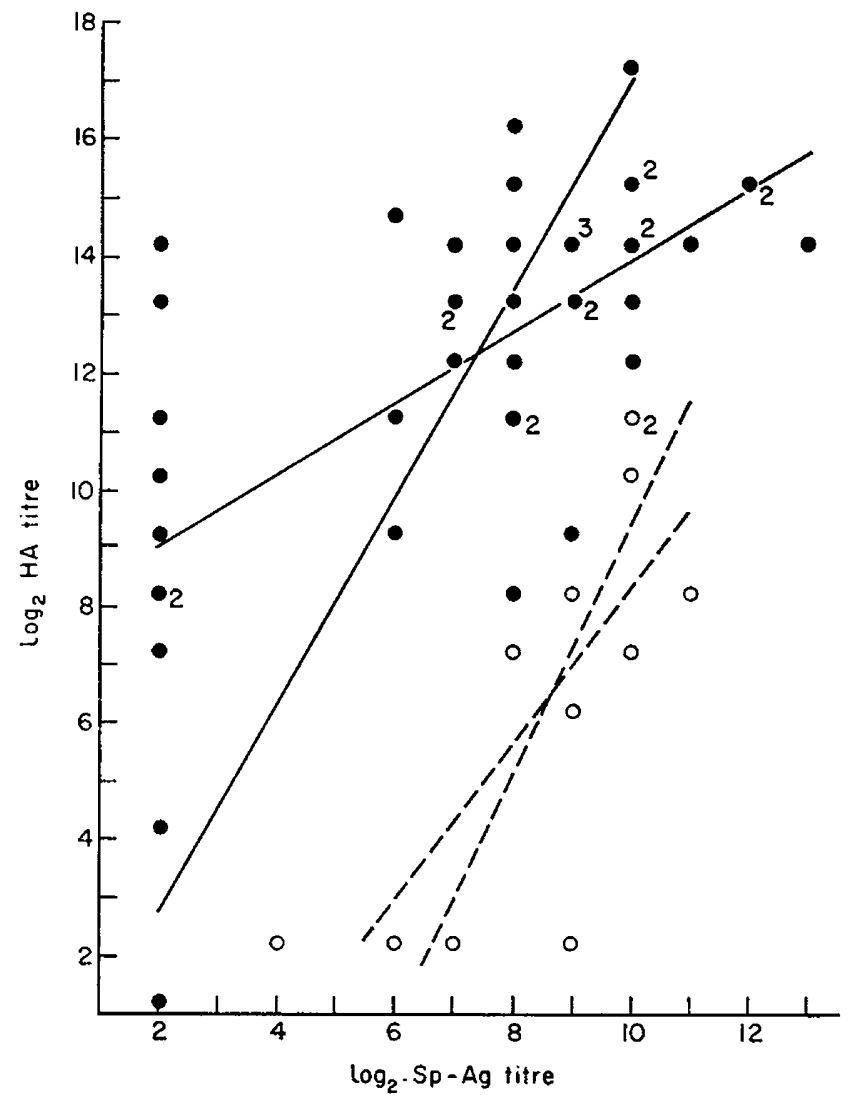

Text-FIG. 3. Regression lines of the correlation between haemagglutination (HA) and sperm agglutination (Sp-Ag) titres after re-immunization in mice injected with the supernatant fraction $(\bullet ; \mathrm{r}=0.63, P<0.001)$ or whole spermatozoa $(0 ; \mathrm{r}=0.78$, $P<0 \cdot 01$ ). (Results from the initial immunization period were similar). Numbers adjacent to points indicate more than one mouse.

\section{Antibody responses}

The serum antibody concentrations in mice immunized against supernatant and sediment fractions were compared. Text-figure 2 gives the group mean titres from the haemagglutination and sperm agglutination tests after the first period of immunization. Titres after re-immunization were higher but differences between groups were similar. The haemagglutination test detected substantial antibody formation in many of the mice injected with sperm-head nuclei (Groups Sed and Sed-A pooled) or whole spermatozoa, but titres were markedly higher again in those injected with the supernatant (Groups Sup and Sup-A). 
The injection of the supernatant also stimulated the formation of sperm agglutinins, causing tail-to-tail agglutination indistinguishable from that produced by intact spermatozoa. Specific head-to-head adherence, similar to that arising against the isolated sperm heads studied by Henle, Henle \& Chambers (1938), was not seen in the mice injected with supernatant, and no sperm agglutinin production at all occurred in the mice injected with sediment (Groups Sed and Sed-A pooled). The formation of sperm agglutinins in response to the injection of the supernatant fraction was abolished by storing the antigen at $-20^{\circ} \mathrm{C}$.

The two immunological assays were compared by a correlation analysis on the paired observations of sperm agglutination and haemagglutination titres for each mouse. Within Group Sp and within the combined Groups Sup + Sup-A, titres from the two assays were significantly correlated (Text-fig. 3). However, since disrupting the spermatozoa markedly increased the haemagglutination but not the sperm agglutination titre, the two assays were probably

\section{TABLE 4}

COEFFICIENTS OF CORRELATION ( $r$ ) AND REgRESSION (b) FOR THE REGRESSION ANALYSIS OF LITTER SIZE (FIRST AND SEGOND LITTER) OR FERTILIZATION RATE ON SERUM TITRES FROM MICE INJEGTED WITH THE SUPERNATANT FRAGTION (GROUP SUP + SUP-A)

\begin{tabular}{c|l|c|c|c|c}
\hline Regression & Assay & No. of mice & $r$ & $b$ & $\mathrm{P}$ \\
\hline Litter size & HA & 43 & -0.399 & -0.913 & $<0 \cdot 01$ \\
on titre & Sp-Ag & 43 & -0.175 & -0.364 & $>0.2$ \\
Fertilization & HA & 31 & -0.240 & $-2 \cdot 261$ & $>0 \cdot 1$ \\
rate on titre & Sp-Ag & 31 & -0.420 & -4.218 & $<0.02$ \\
\hline
\end{tabular}

$\mathrm{HA}=$ haemagglutination; $\mathrm{Sp}-\mathrm{Ag}=$ sperm agglutination

not detecting the same antibodies. The significant regressions within Groups $\mathrm{Sp}$ and Sup + Sup-A could have arisen if mice responding well to the antigens inducing sperm agglutinins also tended to produce high concentrations of antibody detected by the haemagglutination test.

Among the females injected with the supernatant, the regressions of litter size on haemagglutination titre and fertilization rate on sperm agglutination titre were both significant (Table 4) but the correlation coefficients were low. Thus, the serum titres detected by these two assays were of questionable value in reflecting a state of infertility.

\section{DISGUSSION}

Previous investigators have successfully reduced fertility in the female by injecting a variety of species with whole spermatozoa or homogenates of testes emulsified in complete Freund's adjuvant (Menge, 1967, 1968, 1969; Katsh, 1959; Edwards, 1964), in the adjuvant sodium alginate (Bell, 1969b) or without adjuvants (McLaren, 1964; Bell, 1969a). In the present studies, injection of a sub-cellular fraction of spermatozoa was successfully employed to reduce fertility in female mice, showing that whole spermatozoa were not required 
and that the active component could be isolated in the supernatant fraction. Sperm-head nuclei were found to have no effect.

Considerable progress has been made in isolating and purifying testicular antigens that will induce aspermatogenesis (or experimental allergic orchitis) in the male. Initial efforts by Katsh (1960a) were improved by Brown, Holborow \& Glynn (1965), who isolated and purified an active fraction from a phenol extract of guinea-pig testes. Using this pure extract, Brown, Glynn \& Holborow (1967) found that allergic orchitis was induced only in the presence of both circulating antibody and delayed hypersensitivity. Four components of guineapig spermatozoa were isolated by Voisin \& Toullet (1968), three of which induced testicular pathology. The use of extracts of spermatozoa or testis in the female has not been reported to our knowledge. Although the mechanism of antibody action may be different in the two sexes, the effective antigen may well be similar.

Antibodies in the female might impair fertility before fertilization, up to or during implantation, or during post-implantational development. In the present work, results from mice injected with freshly collected spermatozoa confirmed earlier reports by McLaren (1964) and Edwards (1964) that the decline in litter size was due to a failure of eggs to be fertilized. Immunization with the nonsedimented fraction of spermatozoa resulted in a similar failure of fertilization, while the induced sterility observed in iso-immunized rabbits (Bell, 1969b) was also associated with unfertilized eggs. Since McLaren (1964) found fewer spermatozoa in the ampullae of immunized mice, the effect of immunization may have been to prevent spermatozoa from reaching the site of fertilization, rather than to interfere at some point during penetration of the egg.

The suggestion by Katsh $(1958,1960 \mathrm{~b})$ that induced infertility might be explained by a failure of the ovum to implant in a sensitized uterus because of anaphylactic contractions evoked by contact with inseminated spermatozoa, cannot apply to the present results, nor to many of the previous findings (McLaren, 1964; Edwards, 1964; Menge, 1968, 1969), where the effect on fertility is exerted at the time of fertilization.

Menge (1968, 1969) has examined iso-immunized rabbits and cattle (employing Freund's adjuvant) for loss of embryos as well as for failure of fertilization. Although there were significant numbers of embryonic deaths, the major effect was a decreased fertilization rate. One suspects from recent reports of pathological disorders induced by Freund's complete adjuvant (Boss, 1965; Plank, Hunt \& Gohen, 1967; Ram, Glenner \& DeLellis, 1968) that the use of this adjuvant may be contributing a non-immunological factor to the incidence of embryonic deaths.

When fertility is reduced by iso-immunization, it would be of considerable value to identify the type of antibody(s) (e.g. sperm agglutinins, complement fixing, immobilizing, passive haemagglutinins) responsible. Although many assays have been developed to detect antibodies against spermatozoa, few have correlated with infertility. The present results, as well as studies on IgG and IgM classes of iso-antibody against spermatozoa (Bell \& Wood, 1968), show that the passive haemagglutination and sperm agglutination tests are not detecting the same antibodies. The supernatant fraction, by comparison with 
whole spermatozoa, stimulated significantly increased haemagglutination titres but evoked little change in sperm agglutinin production. The disruption procedure could have altered the sperm material injected so as to produce higher concentrations of the same antibodies, or additional antibodies to newly exposed antigenic sites. The increased haemagglutination titres were not associated with a corresponding decrease in fecundity, suggesting that the additional antibody detected (regardless of origin) was not involved with the induced infertility. This observation does not necessarily abolish the value of the assay in detecting 'relevant' antibody, for litter size showed a significant regression on haemagglutination titre if either the supernatant fraction (Table 4) or fresh spermatozoa (Bell, 1969a) were injected.

The relevance of sperm agglutinins is severely questioned by the current investigation. Freezing the supernatant fraction abolished the agglutinins but did not alter the effect on fertilization rate or litter size. McLaren (1966), employing adjuvants, was also able to elevate or depress sperm agglutination titres without changing the degree of impaired fecundity. Menge \& Protzman (1967), inseminating rabbits with spermatozoa treated in vitro with heterologous antisera, found that anti-seminal plasma antibody or anti-conceptus antibody did not prevent spermatozoa from fertilizing rabbit eggs ( $95 \%$ fertilized), in spite of high concentrations of sperm agglutinins. Only spermatozoa incubated with anti-testis or anti-sperm antibody failed to fertilize the eggs. On present evidence, it seems doubtful that sperm-agglutinating antibody by itself is responsible for an immunological decrease in fertility.

The failure of investigators to find an antibody type which consistently correlates with infertility is puzzling. One possibility is that a combination of delayed hypersensitivity and humoral antibody is required, as was reported for experimental allergic orchitis (Brown et al., 1967; Toullet \& Voisin, 1969). Moreover, the ultimate factor may be the local concentration of specific antibody at the site of fertilization (or within the reproductive tract) and need not correlate with humoral levels. In this respect, secretory $\gamma \mathrm{A}$-immunoglobulins may be relevant (see Tomasi \& Bienenstock, 1968). Antibody capable of influencing fecundity may exist in specific molecular classes (e.g. IgG, IgM) which are subject to continuing alterations in concentrations (Bell \& Wood, 1968). Another possibility is that a cell-mediated reaction (e.g. lymphocytesperm cell) is responsible.

Identification of the anatomical component of spermatozoa which contributes to the supernatant fraction and induces infertility might help to elucidate the mechanism of the infertility. Iso-antibody directed against acrosomal enzymes, thought essential for sperm penetration (Austin, 1965; Srivastava, Adams \& Hartree, 1965; Stambaugh \& Buckley, 1968), is unlikely to be involved, since the evidence suggests that spermatozoa do not even reach the site of fertilization. Mitochondrial enzymes responsible for sperm respiration are another possible target for immunological attack but the ability of antibody against mitochondria to suppress cell respiration has been questioned (Dumonde, Roodyn \& Prose, 1965). Indirect evidence suggests that specific cytotoxic antibodies to the sperm cell membrane may play an essential rôle in inducing infertility. For antibody to damage a viable cell, the specific antigen must be 
represented on the cell surface (see Dumonde, 1966). Lance, Ford \& Ruszkiewicz (1968) showed that the most effective fraction for raising a lymphotoxic antiserum was the cell membrane. Voisin \& Toullet (1968) have produced 'spermotoxic' iso-antibodies in guinea-pigs using a sperm-membrane fraction, and various observations suggest that similar antibodies could be operating in the present experiments. In iso-immunized female mice, McLaren (1964) found evidence that fewer spermatozoa than normal were reaching the site of fertilization. Plank (1967) noted that few spermatozoa ever reached the oviduct in iso-immunized guinea-pigs, and those that did were immotile shortly after mating. Rabbit spermatozoa which had been incubated in vitro with heterologous anti-sperm sera were alive at the time of insemination, but failed to fertilize rabbit eggs (Menge \& Protzman, 1967). It seems probable that this was due to a cytotoxic action on the antibody-sensitized sperm cells in the reproductive tract following contact with complement in vivo. Thus, a complement-dependent, cytotoxic antibody induced by the cell membranes of spermatozoa seems more likely to be responsible for the infertility induced in the present experiments than a sperm-agglutinating antibody.

\section{ACKNOWLEDGMENTS}

This investigation was supported by a Public Health Service Fellowship (No. 5-F2-HD, 823-03) from the National Institute of Ghild Health and Human Development (E.B.B.) and by the Ford Foundation (A.McL.).

\section{REFERENCES}

Austin, C. R. (1965) Fertilization. In: Foundation of Developmental Biology Series, p. 70. Ed. G. L. Markert. Englewood Cliffs, N.J.

BELL, E. B. (1969a) Immunological control of fertility in the mouse: a comparison of systemic and intravaginal immunization. F. Reprod. Fert. 18, 183.

BELL, E. B. (1969b) Iso-antibody formation against rabbit spermatozoa and its effect on fertility. $\mathcal{F}$. Reprod. Fert. 20, 519.

BeLl, E. B. \& Wood, A. (1968) Heterogeneity of isoantisera against spermatozoa in hyperimmunized mice. Nature, Lond. 220, 508.

Boss, J. H. (1965) Autoimmune renal disease. The production of autoimmune renal disease in the rat by homoimmunization with organ-heterologous material. Medna \&? Pharmacol. exp. 12, 345.

Brown, P. G., Glyn, L. E. \& Holborow, E. J. (1967). The dual necessity for delayed hypersensitivity and circulating antibody in the pathogenesis of experimental allergic orchitis in guinea-pigs. Immunology, 13, 307.

Brown, P. C., Holborow, E. J. \& GlynN, L. E. (1965) The aspermatogenic antigen in experimental allergic orchitis in guinea-pigs. Immunology, 9, 255.

Dumonde, D. G. (1966) Tissue-specific antigens. Adv. Immunol. 5, 245.

Dumonde, D. C., Roodyn, D. B. \& Prose, P. H. (1965) The effects of antibodies on cells. III. Studies on the interaction of rat liver mitochondria and lysosomes with antibody and complement. Immunology, 9, 177.

Edwards, R. G. (1964) Immunological control of fertility in female mice. Nature, Lond. 203, 50.

Henle, W., Henle, G. \& Chambers, L. A. (1938) Studies on the antigenic structure of some mammalian spermatozoa. 7. $\exp$. Med. 68, 335.

Isojima, S., Graham, R. M. \& Graham, J. B. (1959) Sterility in female guinea pigs induced by injection with testis. Science, N.Y. 129, 44.

KATsH, S. (1958) Demonstration in vitro of anaphylactoid response of the uterus and ileum of guinea pig, injected with testis or sperm. F. exp. Med. 107, 95 .

Katsh, S. (1959) Infertility in female guinea pigs induced by injection of homologous sperm. Am. 7 . Obstet. Gynec. 78, 276.

KATSH, S. (1960a) Localization and identification of anti-spermatogenic factor in guinea pig testicles. Int. Archs Allergy appl. Immun. 16, 241. 
KATSH, S. (1960b) The anaphylactogenicity of testicular hyaluronidase and a species difference in testicular hyaluronidase demonstrated by isolated organ anaphylaxis. Int. Archs Allergy appl. Immun. 17, 70 .

LANce, E. M., Ford, P. J. \& Ruszkiewicz, M. (1968) The use of subcellular fractions to raise anti-lymphocytic serum. Immunology, 15, 571 .

McLaren, A. (1962) Does immunity to male antigen affect female reproductive performance? Nature, Lond. 195, 1323.

Mclaren, A. (1964) Immunological control of fertility in female mice. Nature, Lond. 201, 582.

Mclaren, A. (1966) Studies on the isoimmunization of mice with spermatozoa. Fert. Steril. $17,492$.

Menge, A. C. (1967) Induced infertility in cattle by iso-immunization with semen and testis. F. Reprod. Fert. 13, 445.

Menge, A. C. (1968) Fertilization, embryo and fetal survival rates in rabbits isoimmunized with semen, testis, and conceptus. Proc. Soc. exp. Biol. Med. 127, 1271.

Menge, A. G. (1969) Early embryo mortality in heifers isoimmunized with semen and conceptus. $\mathcal{J}$. Reprod. Fert. 18, 67.

Menge, A. C. \& Protzman, W. P. (1967) Origin of the antigens in rabbit semen which induce antifertility antibodies. F. Reprod. Fert. 13, 31.

Plank, S. J. (1967) Mechanisms of experimental immuno-infertility. In: Proceedings of the Eighth Conference of the International Planned Parenthood Federation, p. 403. Ed. R. K. B. Hankinson. IPPF.

Plank, S. J., Hunt, R. D. \& Cohen, A. S. (1967) Amyloidosis in guinea-pigs immunized with sperm and adjuvant. Nature, Lond. 214, 1368.

Ram, J. S., Glenner, G. G. \& DeLellis, R. A. (1968) Amyloid. I. Use of Freund's adjuvant in experimental amyloidosis. Proc. Soc. exp. Biol. Med. 127, 854.

Srivastava, P. N., Adams, C. E. \& Hartree, E. F. (1965) Enzymatic action of lipoglycoprotein preparations from sperm acrosomes on rabbit ova. Nature, Lond. 205, 498.

Stambaugh, R. \& Buckley, J. (1968) Zona pellucida dissolution enzymes of the rabbit sperm head. Science, N.Y. 161, 585.

Tomasi, T. B. \& Bienenstock, J. (1968) Secretory immunoglobulins. Adv. Immunol. 9, 1.

Toullet, F. \& Voisin, G. A. (1969) Réactions d'hypersensibilité et anticorps sériques envers les autoantigènes de spermatozoïdes. Relations avec le mécanisme de l'orchite aspermatogénétique auto-immune. Annls Inst. Pasteur, Paris, 116, 579.

Voisin, G. A. \& Toullet, F. (1968) Étude sur l'orchite aspermatogénétique auto-immune et les autoantigènes de spermatozoïdes chez le cobaye. Annls Inst. Pasteur, Paris, 114, 727. 